\title{
TREATMENT SELECTION FOR FIRST-LINE METASTATIC RENAL CELL CARCINOMA (mRCC) IN AUSTRALIA: IMPACT OF NEW THERAPY OPTIONS
}

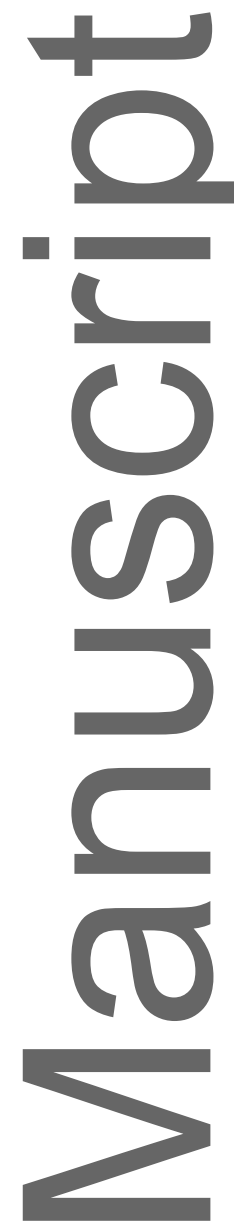

Andrew Schmidt, ${ }^{1}$ Arun Azad, ${ }^{2}$ Jeffrey Goh, ${ }^{3}$ Carole Harris, ${ }^{4}$ Anthony M. Joshua, ${ }^{5}$ Andrew Weickhardt, ${ }^{6}$ Laurence Krieger ${ }^{7}$

${ }^{1}$ Liz Plummer Cancer Centre, Lake Street, Cairns, Queensland, Australia; ${ }^{2}$ Peter McCallum Cancer Centre, 305 Grattan Street, Melbourne, Victoria, Australia; ${ }^{3}$ Royal Brisbane and Women's Hospital, Butterfield Street, Herston \& University of Queensland, St Lucia, Queensland, Australia; ${ }^{4}$ St George Hospital and Sutherland Clinical School UNSW, Gray Street, Kogarah, New South Wales, Australia; ${ }^{5}$ The Kinghorn Cancer Centre, 370 Victoria Street, Darlinghurst, New South Wales, Australia; 6 Olivia Newton-John Cancer Research Institute, 145 Studley Road, Heidelberg, Victoria, Australia; ${ }^{7}$ Royal North Shore Hospital, Reserve Rd, St Leonards, Northern Cancer Institute, 38 Pacific Highway, St Leonards, New South Wales, Australia

Running Title [ $4 \mathbf{4 0}$ characters]: First line treatment of metastatic RCC

\section{Corresponding Author:}

Andrew Schmidt

Liz Plummer Cancer Care Centre

249-251 Lake Street, Cairns North, 4870

Queensland, Australia

andrew.schmidt@uqconnect.edu.au

0742266596

Funding: The development of this manuscript was supported by Novartis Pharmaceuticals Australia, the manufacturer of everolimus and pazopanib.

Acknowledgments: The authors thank Katie Burslem, CMPP of WriteSource Medical Pty Ltd, Sydney, Australia, for providing medical writing support by preparing the manuscript outline, developing the first draft and collating and incorporating author comments to the final draft. Medical writing support was funded by Novartis Pharmaceuticals Australia in accordance with Good Publication Practice (GPP3) guidelines (http://www.ismpp.org/gpp3).

This is the author manuscript accepted for publication and has undergone full peer review but has not been through the copyediting, typesetting, pagination and proofreading process, which may lead to differences between this version and the Version of Record. Please cite this article as doi: $\underline{10.1111 / \text { ajco.13289. }}$.

This article is protected by copyright. All rights reserved. 


\begin{abstract}
Vascular endothelial growth factor (VEGF) receptor tyrosine kinase inhibitors (TKIs) have provided an effective standard of care for the treatment of metastatic clear cell renal cell carcinoma (mRCC). Survival is prolonged with emergence of modern immuno-oncology (IO) combination regimens. Prognostic risk assessment is essential for choosing between these therapies to determine the most appropriate first line treatment option, with selection based on International Metastatic RCC Database Consortium (IMDC) Risk Category. We review the current subsidized first line treatments for mRCC in Australia and consider the evidence for treatment selection and sequencing.
\end{abstract}

Keywords: renal cell carcinoma, VEGF tyrosine kinase inhibitors, immuno-oncology 


\section{Background}

Metastatic kidney cancer is diagnosed in approximately 1,100 individuals per year in Australia. ${ }^{1,2}$ Clear cell renal cell carcinoma (RCC) makes up $80 \%$ of kidney cancer cases. ${ }^{3}$ First Line vascular endothelial growth factor (VEGF) receptor tyrosine kinase inhibitor (TKIs) therapy has been an effective standard of care treatment for metastatic clear cell RCC (mRCC) since 2007 when sunitinib reported a progression free survival (PFS) advantage over interferon with patients reaching a median overall survival (OS) in excess of two years. ${ }^{4}$ However, the treatment landscape is evolving rapidly with the emergence of immuno-oncology (IO) combinations now demonstrating an OS benefit compared to the VEGF TKI sunitinib.5,6

Critical to guiding treatment choice is the assessment of prognostic risk criteria which segregate patients into favorable risk, intermediate risk and unfavorable risk groups. ${ }^{7}$ Further practical considerations need to be considered including drug availability and subsidization. In Australia, given our universal health care system drugs are not only registered with the Therapeutic Goods Administration (TGA), but then may be subsidized for use via the Pharmaceutical Benefits Scheme (PBS). First line TKIs sunitinib and pazopanib have been subsidized in Australia for a decade. After demonstrating an OS advantage, IO doublet therapy with nivolumab and ipilimumab was listed on the PBS in March 2019 for first line treatment of mRCC for patients with intermediate- and unfavorable risk disease. In light of this, and the uncertainty around treatment selection and sequencing, we review clinical considerations, (including risk assessment) and appraise the evidence for first line treatment options for mRCC in Australia, and the impact on subsequent therapeutic decisions.

\section{Assessing risk}

Prognostic risk factors for survival in mRCC inform accurate clinical trial design, patient counseling and risk-specific treatment decisions. In the earliest model, Motzer et al identified five prognostic factors that were found to correlate with OS in mRCC, known as the Memorial Sloan-Kettering Cancer Center (MSKCC) Score. ${ }^{8}$ These included low Karnofsky performance status (less than 80\%), high lactate dehydrogenase (greater than one and half times the upper limit of normal (ULN)), low serum hemoglobin, high corrected serum calcium (greater than $10 \mathrm{mg} / \mathrm{dL}(2.5 \mathrm{mmol} / \mathrm{L}))$, and time from initial RCC diagnosis to start of therapy of less than one year. Patients with zero risk factors were considered to have favorable risk, those with one or two risk factors were intermediate risk and patients with three or more risk factors had an unfavorable risk profile. Survival profiles differed between the risk groups, with 20 months, 10 months and 4 months OS seen in each of the groups respectively.

These prognostic factors were identified during the era of early IO therapy with interferonbased treatment and from a retrospective analysis in a single institution so it was unclear whether they would be relevant for patients receiving VEGF TKI therapy in a generalized population. Following the development of targeted therapy, Heng et al further expanded and validated the model through the International Metastatic RCC Database Consortium (IMDC). ${ }^{9}$ The Heng/IMDC criteria no longer include lactate dehydrogenase levels but do include increased neutrophil count (greater than the ULN) and raised platelets (greater than the ULN).

This article is protected by copyright. All rights reserved. 
Table 1 shows the estimates of survival with these revised criteria for each risk group.
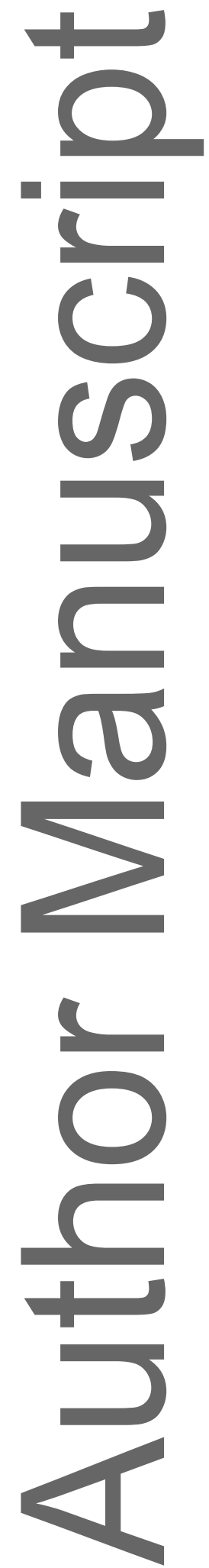

This article is protected by copyright. All rights reserved. 
Table 1: IMDC Criteria for Prognostic Assessment

\begin{tabular}{|c|c|c|c|}
\hline & Number of Risk Factors & Risk Group & $\begin{array}{l}\text { Median Overall Survival } \\
\text { (months) }(95 \% \mathrm{CI})\end{array}$ \\
\hline & 0 & Favorable & $43.2(31.4-50.1)$ \\
\hline & 1 to 2 & Intermediate & $22.5(18.7-25.1)$ \\
\hline & 3 to 6 & Unfavorable & $7.8(6.5-9.7)$ \\
\hline
\end{tabular}

In Australia, PBS criteria follow the IMDC model for risk stratification, so this model is relevant to making treatment decisions in the Australian environment.

\section{Current Treatment Landscape for mRCC in Australia}

The Australian health care system subsidizes high cost therapies for use in the indication for which they are approved based on clinical trial data. There are currently no Australian Guidelines for treatment selection for patients with mRCC. Australian clinicians prescribe within the PBS framework based on available clinical trial data, which historically has paralleled the European Society for Medical Oncology (ESMO) and the National Comprehensive Cancer Network (NCCN) guidelines. ${ }^{10,11}$

\section{First Line Treatment Options}

Treatment selection in mRCC depends on the IMDC risk group. We review the evidence for surgery, in particular cytoreductive nephrectomy, treatment with VEGF TKIs and IO therapy options for each of the risk categories and provide a decision matrix to assist with treatment of Australian patients. Figure 1 shows the current Australian first line treatment options for mRCC.

\section{Observation}

mRCC may follow a prolonged period without significant tumor growth, thus observation is a safe and reasonable approach for carefully selected patients. This cohort is enriched with patients demonstrating more indolent disease, which tend to have lower numbers of IMDC risk factors and a lower volume or fewer sites of metastatic disease.12,13 Patients with a low volume of metastatic disease at favorable sites (such as nodal or pulmonary disease) may be suitable for resection of metastases, with a view to time off systemic treatment and active surveillance. ${ }^{14}$

\section{Cytoreductive Nephrectomy}

Cytoreductive nephrectomy $(\mathrm{CN})$ is an important treatment consideration prior to systemic therapy for patients with low volume metastatic disease, a good performance status and with favorable or intermediate risk disease.10,11,15 However, $\mathrm{CN}$ is not recommended for unfavorable risk and many intermediate risk patients who require systemic therapy based on sites of disease and the tempo of progression, or in the presence of other poor prognostic features such as central nervous system metastases.

Patients with mRCC may require a nephrectomy to control tumor-related symptoms. In the cytokine treatment era $\mathrm{CN}$ was recommended for patients with an asymptomatic primary tumor and good performance status based on combined analysis of two trials demonstrating a survival

This article is protected by copyright. All rights reserved. 
advantage. ${ }^{16-18}$ The SURTIME and CARMENA studies explored the benefit of CN in the context of systemic treatment with sunitinib. ${ }^{19,20}$

The SURTIME clinical trial was designed to investigate the safety of delayed nephrectomy following upfront TKI treatment. ${ }^{19}$ Unfortunately, the trial was underpowered secondary to poor accrual, recruiting only 99 patients over 5.7 years. All patients had mRCC, a resectable primary tumor and three or fewer surgical risk factors. A majority (88\%) had MSKCC intermediate risk disease. Patients were randomized to receive either $\mathrm{CN}$ prior to or following treatment with sunitinib. Although the primary endpoint was initially PFS, due to poor recruitment the reported analysis was changed to intention to treat (ITT) 28-week progression free rate (PFR). For patients receiving immediate CN, the 28 -week PFR was $42 \%$ ( $n=50 ; 90 \%$ CI $30 \%$ to $55 \%)$ compared with $43 \%(\mathrm{n}=49 ; 90 \%$ CI $31 \%$ to $56 \%$; $\mathrm{p}=0.61)$ in the deferred $\mathrm{CN}$ arm. Median OS was 32.4 months (95\% CI 14.5 to 65.3 months) for deferred CN compared with 15.0 months (95\% CI 9.3 to 29.5 months) for immediate CN (hazard ratio (HR) 0.57 ; (95\% CI 0.34 to $0.95 ; \mathrm{p}=0.03)$ ). Although poor recruitment limited the trial, delayed nephrectomy was feasible and well tolerated, and patients completing this approach had a prolonged OS, suggesting patients may benefit from initial control of systemic disease, followed by consolidation nephrectomy for patients who respond with TKI treatment.

The CARMENA trial was designed to compare $\mathrm{CN}$ followed by sunitinib with sunitinib alone in 450 patients with mRCC. 15,20 The study met the primary endpoint demonstrating non-inferiority to sunitinib alone, challenging the mainstay of upfront nephrectomy for patients with mRCC. Sunitinib was dosed at $50 \mathrm{mg}$ daily in 28-day cycles on and 14 days off every six weeks. The primary endpoint was OS. While MKSCC criteria were used for the interim analysis, IMDC criteria were applied for the final analysis. When stratified using MSKCC criteria, no significant differences between arms were identified. Based on IMDC risk assessment $58.6 \%$ of patients were considered intermediate risk and $41.4 \%$ were considered unfavorable risk. After 61.5 months of follow-up, median OS was 15.6 months and 19.8 months in the CN followed by sunitinib and sunitinib only groups respectively (HR 0.96; $95 \%$ CI 0.78 to 1.18 ) demonstrating that the results of the sunitinib only group were non-inferior to those in the CN followed by sunitinib group. Of those patients in the intermediate risk group, with two risk factors $(51.9 \%$, mostly low hemoglobin, high corrected calcium or neutrophils), a significant difference in favor of the sunitinib alone group was demonstrated with a median OS of 16.6 months and 31.2 months respectively (HR $0.61 ; 95 \%$ CI 0.41 to $0.91 ; p=0.015$ ). However, of the $48.1 \%$ of patients in the intermediate risk group who had just one risk factor (interval between diagnosis and treatment less than one year) there may be some benefit for the use of $\mathrm{CN}$ in combination with sunitinib compared with sunitinib alone (median OS 30.5 months vs. 25.2 months, HR 1.24; 95\% CI 0.81 to 1.90). ${ }^{15}$ In addition, no significant difference was found for patients with only one metastatic site. However, these comparative sub-group analyses were not pre-specified, so these are hypothesis generating results rather than definitive. Lastly, 40 patients had secondary nephrectomy after treatment with sunitinib alone, with a median OS of 48.5 months $(95 \% \mathrm{CI}$ 27.9 to 64.4 ) after nephrectomy compared with 15.7 months (95\% CI 13.3 to 20.5) for patients who never had surgery. Most patients in this group underwent $\mathrm{CN}$ after achieving an excellent response to sunitinib at metastatic sites, so there is a clear selection bias favoring better outcomes in this group.

This article is protected by copyright. All rights reserved. 
The CARMENA trial provides sound evidence that not all patients need a nephrectomy. However, it is important to recognize potential trial limitations that limit the externalization of results. This population was enriched with unfavorable risk patients harboring a large volume of measurable disease that had a need for immediate upfront systemic therapy. This is not representative of patients who would most likely benefit from nephrectomy, commonly favorable risk patients, those with solitary sites of metastatic disease, patients with small volume lung metastases, or those with intermediate disease and one risk factor. CN should still be considered in those patients as part of a systemic treatment plan.

Moving forward, the applicability of this data to a population that is receiving more potent systemic treatment incorporating IO agents is now unclear. Attractive strategies for investigation include upfront IO treatment followed by nephrectomy, avoiding a treatment-free period following nephrectomy to allow wound healing. With deeper responses to contemporaneous treatment, the role of consolidative nephrectomy will also need to be considered. New data will be needed to guide clinicians as this space evolves. A large international multicenter randomized phase III trial (NORDIC-SUN-Trial) is planned to evaluate this in the setting of first line ipilimumab and nivolumab. ${ }^{21}$ The trial intends to evaluate the survival benefit for delayed $\mathrm{CN}$ versus no nephrectomy in intermediate and unfavorable risk patients.

\section{Consolidative Nephrectomy and Metastases Directed Therapy}

Patients who experience a significant response to first line treatment may benefit from consolidative treatment with $\mathrm{CN}$ or metastases directed therapy such as stereotactic radiotherapy or resection. Patients suitable for this approach harbor a limited burden of extrarenal disease and may have a significant reduction in their systemic disease burden by consolidative therapy. ${ }^{14,22}$

\section{First Line Systemic Treatment Selection}

\section{Favorable Risk Disease}

Favorable risk patients requiring first line systemic treatment currently have access to the PBS options of sunitinib and pazopanib. ${ }^{23}$

For sunitinib the pivotal randomized controlled trial (RCT) allocated patients with previously untreated mRCC to receive either sunitinib 50mg daily (four weeks on, two weeks off) or interferon alfa (9MU subcutaneously three times weekly). ${ }^{4}$ Sunitinib demonstrated longer PFS and higher responses rates compared with interferon alfa (Table 2).4,24 A retrospective analysis of this study using IMDC risk criteria has demonstrated the PFS benefit of sunitinib is greater in the favorable and intermediate risk groups compared with the unfavorable risk group. ${ }^{25}$

Pazopanib has demonstrated non-inferiority against sunitinib (Table 2). Although considered therapeutically equivalent these agents differ in the expected range of clinical toxicity. Sunitinib carries a higher incidence of fatigue, hand-foot syndrome and thrombocytopenia, pazopanib conferring a greater risk of liver function test derangement. ${ }^{26}$

This article is protected by copyright. All rights reserved. 
Table 2 Summary of Sunitinib and Pazopanib Registration Trials

\begin{tabular}{|c|c|c|c|c|c|}
\hline & & \multicolumn{2}{|c|}{ Sunitinib vs Interferon-alfa ${ }^{24}$} & \multicolumn{2}{|c|}{ COMPARZ $^{26}$} \\
\hline & Treatment & $\begin{array}{l}\text { Sunitinib } \\
(n=375)\end{array}$ & $\begin{array}{l}\text { Interferon alfa } \\
\qquad(n=375)\end{array}$ & $\begin{array}{l}\text { Sunitinib } \\
(n=553)\end{array}$ & $\begin{array}{l}\text { Pazopanib } \\
(n=557)\end{array}$ \\
\hline \multirow[t]{5}{*}{ - } & $\begin{array}{l}\text { Median PFS, months } \\
(95 \% \mathrm{CI})\end{array}$ & $\begin{array}{c}11 \\
\text { (11 to } 13)\end{array}$ & $\begin{array}{c}5 \\
(4 \text { to } 6)\end{array}$ & $\begin{array}{c}9.5 \\
(8.3 \text { to } 11.1)\end{array}$ & $\begin{array}{c}8.4 \\
(8.3 \text { to } 10.9)\end{array}$ \\
\hline & $\begin{array}{l}\text { PFS Hazard Ratio } \\
(95 \% \mathrm{CI})\end{array}$ & \multicolumn{2}{|c|}{$\begin{array}{c}0.54 \\
(0.45 \text { to } 0.64 ; p<0.001)\end{array}$} & \multicolumn{2}{|c|}{$\begin{array}{c}1.05 \\
(0.90 \text { to } 1.22)\end{array}$} \\
\hline & $\begin{array}{l}\text { Median OS, months } \\
(95 \% \mathrm{CI})\end{array}$ & $\begin{array}{c}26.4 \\
(23.0 \text { to } 32.9)\end{array}$ & $\begin{array}{c}21.8 \\
(17.9 \text { to } 26.9)\end{array}$ & $\begin{array}{c}29.3 \\
(25.3 \text { to } 32.5)\end{array}$ & $\begin{array}{c}28.4 \\
(26.2 \text { to } 35.6)\end{array}$ \\
\hline & $\begin{array}{l}\text { OS Hazard Ratio } \\
(95 \% \mathrm{CI})\end{array}$ & \multicolumn{2}{|c|}{$\begin{array}{c}0.82 \\
(0.67 \text { to } 1.00 ; p=0.051)\end{array}$} & \multicolumn{2}{|c|}{$\begin{array}{c}0.91 \\
(0.76 \text { to } 1.08 ; p=0.28)\end{array}$} \\
\hline & $\begin{array}{l}\text { ORR } \\
(95 \% \mathrm{CI})\end{array}$ & $\begin{array}{c}47 \% \\
(42 \% \text { to } 52 \%)\end{array}$ & $\begin{array}{c}12 \% \\
(9 \% \text { to } 16 \% ; \\
p<0.001)\end{array}$ & $\begin{array}{c}25 \% \\
(21 \% \text { to } 28 \%)\end{array}$ & $\begin{array}{c}31 \% \\
(27 \% \text { to } 35 \% ; p=0.03)\end{array}$ \\
\hline
\end{tabular}

ORR = objective response rate; OS = overall survival; PFS = progression free survival

Analysis of real-world evidence has also shown similar efficacy for both sunitinib and pazopanib. ${ }^{27}$ Dose schedule optimization is an important part of enhancing treatment response on TKI therapy. Patients require close clinical and laboratory monitoring to recognize toxicity and maximize the drug dose and exposure, which has been shown to correlate with response. For example, dose optimization of sunitinib therapy according to toxicities ${ }^{28}$ has been associated with prolonged OS compared to dosing using four weeks on and two weeks off. The longest reported OS was 38.5 months by Bjarnason et al (95\% CI 28.3 to not reached) using individualized schedules. ${ }^{29}$

\section{Intermediate and Unfavorable Risk Disease - Immuno-Oncology}

IO doublet therapy with ipilimumab in combination with nivolumab has been PBS listed after demonstrating an OS advantage and improved objective response rate (ORR) over sunitinib in patients with intermediate and unfavorable risk disease. For patients suitable for IO treatment and fit enough to receive the combination, this should be considered a new standard of care. ${ }^{5}$ In the pivotal phase III RCT 1,096 patients were randomly assigned to receive either nivolumab (3 $\mathrm{mg} / \mathrm{kg}$ ) plus ipilimumab (1 mg/kg) intravenously every three weeks for four doses, followed by maintenance nivolumab (3 mg/kg) every two weeks, or sunitinib $(50 \mathrm{mg}$ ) orally once daily for 4 weeks (6-week cycle). OS, PFS and ORR among intermediate and unfavorable risk patients were co-primary endpoints. A post hoc analysis of this study demonstrated consistent efficacy across all IMDC risk groups for ipilimumab plus nivolumab but decreased efficacy of sunitinib with as

This article is protected by copyright. All rights reserved. 
the number of risk factors increased. ${ }^{30}$ With regards to toxicity, $35 \%$ of patients receiving ipilimumab plus nivolumab required glucocorticoid treatment at a dose of greater than $40 \mathrm{mg} /$ day of prednisone or equivalent for immune related adverse events, which led to treatment discontinuation in $22 \%$ of patients.

In favorable risk patients, sunitinib outperformed ipilimumab plus nivolumab with a higher response rate of $52 \%$ (95\% CI $43 \%$ to $61 \%$ ) vs. $29 \%$ (95\% CI $21 \%$ to $38 \%$ ) and median PFS of 25.1 months (95\% CI 20.9 to not estimable) vs. 15.3 months (95\% CI 9.7 to 20.3 months). ${ }^{5}$ OS favored sunitinib at 18 months, $93 \%$ (95\% CI 87\% to 97\%) vs. 88\% (95\% CI 80\% to $92 \%$ ). The chance of complete response however, is still much greater for those that receive doublet IO in the first line setting. While not reimbursed for patients with favorable risk disease, one does have to speculate whether young, fit patients should be given the opportunity for a more durable and deep response, accepting that the majority will have the option of salvage or second line therapies and beyond if needed.

The trial of ipilimumab plus nivolumab excluded patients with a past history of or active autoimmune disease, viral infections such as human immunodeficiency virus (HIV) or hepatitis B and $\mathrm{C}$, and organ transplants. Although retrospective data suggests the chance of reactivation of auto-immune conditions occurs in approximately $30 \%$ to $40 \%$ of these patients, mostly these episodes of reactivation were rapidly and successfully treated with steroids. ${ }^{31,32}$ Additionally there was no clear reduction in the effectiveness of the IO treatment. Whether this applies to patients with a concurrent flare of their auto-immune disorder receiving active treatment with high doses of immunosuppression or steroids is unclear as these patients were typically not included in even the retrospective series. Recent data suggests that immunotherapy is well tolerated in patients with treated HIV, or concurrent hepatitis B and C.33-35 Given the risk of organ rejection with IO, patients with organ transplants should not receive IO treatment. 36,37

Clinicians prescribing ipilimumab in combination with nivolumab should be familiar with the wide and potentially serious consequences of immune-mediated toxicity and have sufficient infrastructure and expertise to manage toxicities if they arise. In the setting of rare or severe immune-mediated events, consultation with a high-volume center with familiarity in managing these events is advisable. Patients should be well educated to the encountered spectrum of toxicity and have clear pathways to seek emergency care in the setting of an adverse event.

\section{Intermediate and Unfavorable Risk Disease - Tyrosine Kinase Inhibitors}

Factors that may preclude the use of IO agents include solid organ transplantation, active autoimmune disease, or a history of auto-immune disease where the consequences of reactivation may be significant. For patients unsuitable for IO treatment, TKIs remain the standard of care in this population.

In Australia, sunitinib and pazopanib are only subsidized in the intermediate risk group with no subsidized alternatives for unfavorable risk disease. Cabozantinib is an additional TGAregistered option in intermediate and unfavorable risk disease, although is only PBS subsidized in the second line setting. 23,38

This article is protected by copyright. All rights reserved. 


\section{Second Line Treatment options}

Reimbursed treatment options following first line VEGF TKI therapy in Australia include nivolumab, cabozantinib, axitinib, everolimus or sorafenib. ${ }^{23}$ The combination of lenvatinib and everolimus is TGA-approved but not reimbursed. Table 3 summarizes the key evidence for second line treatment of mRCC.

Nivolumab reimbursement for mRCC following progression on a TKI is based on the large randomized phase 3 trial CHECKMATE 025 involving 821 patients and that met its primary endpoint improving OS compared to everolimus. ${ }^{39}$ The safety profile of nivolumab was consistent with that seen in other studies of this drug, with $19 \%$ of patients experiencing grade 3-4 toxicity.

Cabozantinib gained PBS reimbursement following progression on VEGF targeted therapy meeting its primary endpoint of prolonging PFS and OS compared with everolimus in the phase III METEOR trial involving 658 patients. ${ }^{40,41}$

Lenvatinib TGA approval for patients who have progressed on TKI therapy is based on the small 150 patient randomized phase II study HOPE 205.42 Comparing (in a 1:1:1 ratio) lenvatinib plus everolimus with lenvatinib monotherapy and everolimus monotherapy, lenvatinib plus everolimus demonstrated a significant median PFS benefit compared to everolimus. The trial was not powered to detect an OS advantage but favors the lenvatinib plus everolimus arm, not meeting the boundary of statistical significance. ${ }^{43,44}$ Lenvatinib plus everolimus combination therapy led to dose reduction in $71 \%$ of patients, the most common grade 3 or greater adverse events included diarrhea, fatigue and hypertension.

Axitinib is PBS reimbursed following progression on a TKI based on the phase III AXIS study demonstrating a PFS benefit over sorafenib. ${ }^{45}$ Axitinib treatment was discontinued because of toxicity in 14 (4\%) of 359 patients, most frequent adverse events being diarrhea, hypertension and fatigue. Dose escalation of axitinib was allowed on this trial.

Activation of the mammalian target of rapamycin (mTOR) pathway has been correlated with aggressive behavior and poor prognosis in RCC tumors. Everolimus, an mTOR inhibitor, is PBS listed prolonging PFS over placebo in patients pretreated with a VEGF TKI. ${ }^{46}$

Sorafenib is a VEGF TKI which has shown activity over placebo following progression on a TKI in the phase III TARGET trial. ${ }^{47}$ Just under a third (29\%) of patients experienced grade 3 or greater toxicity, most commonly diarrhea, fatigue, hypertension, hand-foot skin reaction, and rash or desquamation.

This article is protected by copyright. All rights reserved. 
Table 3: Comparison of Trials for VEGF Refractory Advanced Clear Cell Kidney Cancer

\begin{tabular}{|c|c|c|c|c|c|c|c|c|c|c|c|c|c|}
\hline $\begin{array}{l}\text { Trial } \\
\text { Name }\end{array}$ & \multicolumn{2}{|c|}{ RECORD-1 $^{46}$} & \multicolumn{2}{|c|}{ AXIS $^{45,48}$} & \multicolumn{2}{|c|}{$\begin{array}{c}\text { CheckMate } \\
025^{48}\end{array}$} & \multicolumn{2}{|c|}{ METEOR $^{41}$} & \multicolumn{3}{|c|}{ HOPE-205 ${ }^{42-44}$} & \multicolumn{2}{|c|}{ TARGET $^{47,49}$} \\
\hline $\begin{array}{l}\text { Treat } \\
\text { ment }\end{array}$ & $\begin{array}{c}\text { Evero } \\
\text { limus } \\
(\mathrm{n}= \\
272)\end{array}$ & $\begin{array}{c}\text { Place } \\
\text { bo } \\
(n= \\
138)\end{array}$ & $\begin{array}{c}\text { Axiti } \\
\text { nib } \\
(n= \\
361)\end{array}$ & $\begin{array}{c}\begin{array}{c}\text { Soraf } \\
\text { enib }\end{array} \\
(n= \\
362)\end{array}$ & $\begin{array}{c}\text { Nivol } \\
\text { umab } \\
(n= \\
410)\end{array}$ & $\begin{array}{c}\text { Evero } \\
\text { limus } \\
(n= \\
411)\end{array}$ & $\begin{array}{c}\text { Caboza } \\
\text { ntinib } \\
(n= \\
330)\end{array}$ & $\begin{array}{c}\text { Evero } \\
\text { limus } \\
(n= \\
328)\end{array}$ & $\begin{array}{c}\text { Lenva } \\
\text { tinib } \\
+ \\
\text { everol } \\
\text { imus } \\
\\
(n= \\
51)\end{array}$ & $\begin{array}{c}\begin{array}{c}\text { Lenva } \\
\text { tinib }\end{array} \\
(n= \\
52)\end{array}$ & $\begin{array}{c}\text { Evero } \\
\text { limus } \\
(\mathrm{n}= \\
50)\end{array}$ & $\begin{array}{c}\begin{array}{c}\text { Soraf } \\
\text { enib }\end{array} \\
(n= \\
451)\end{array}$ & $\begin{array}{l}\begin{array}{l}\text { Plac } \\
\text { ebo }\end{array} \\
(n= \\
452)\end{array}$ \\
\hline $\begin{array}{l}\text { Media } \\
\mathrm{n} \text { PFS, } \\
\text { mont } \\
\text { hs } \\
(95 \% \\
\text { CI) }\end{array}$ & $\begin{array}{c}4.0 \\
(3.7 \text { to } \\
5.5)\end{array}$ & $\begin{array}{c}1.9 \\
(1.8 \\
\text { to } \\
1.9)\end{array}$ & $\begin{array}{l}6.7 \\
(6.3 \\
\text { to } \\
8.6)\end{array}$ & $\begin{array}{l}4.7 \\
(4.6 \\
\text { to } \\
5.6)\end{array}$ & $\begin{array}{c}4.6 \\
(3.7 \text { to } \\
5.4)\end{array}$ & $\begin{array}{c}4.4 \\
(3.7 \text { to } \\
5.5)\end{array}$ & $\begin{array}{c}7.4 \\
(6.6 \text { to } \\
9.1)\end{array}$ & $\begin{array}{c}3.9 \\
(3.7 \text { to } \\
5.1)\end{array}$ & $\begin{array}{c}12.8 \\
(7.4 \text { to } \\
17.5)\end{array}$ & $\begin{array}{c}9.0 \\
(5.6 \text { to } \\
10.2)\end{array}$ & $\begin{array}{c}5.6 \\
(3.6 \text { to } \\
9.3)\end{array}$ & $\begin{array}{l}5.5 \\
\text { (not } \\
\text { repor } \\
\text { ted) }\end{array}$ & $\begin{array}{l}2.8 \\
\text { (not } \\
\text { repo } \\
\text { rted) }\end{array}$ \\
\hline $\begin{array}{l}\text { PFS } \\
\text { Hazar } \\
\text { d } \\
\text { Ratio } \\
(95 \% \\
\text { CI })\end{array}$ & \multicolumn{2}{|c|}{$\begin{array}{c}0.30(0.22 \text { to } \\
0.40)\end{array}$} & \multicolumn{2}{|c|}{$\begin{array}{c}0.67 \\
(0.55 \text { to } 0.81 \\
p<0.0001)\end{array}$} & \multicolumn{2}{|c|}{$\begin{array}{c}0.88 \\
(0.75 \text { to } 1.03 ; \mathrm{p} \\
=0.11)\end{array}$} & \multicolumn{2}{|c|}{$\begin{array}{c}0.51 \\
(0.41 \text { to } 0.62 ; p< \\
0.0001)\end{array}$} & \multicolumn{3}{|c|}{$0.45(0.27$ to 0.79$)$} & \multicolumn{2}{|c|}{$\begin{array}{c}0.44 \\
(0.35 \text { to } 0.55 \\
p<0.000001)\end{array}$} \\
\hline $\begin{array}{l}\text { Media } \\
\text { n OS, } \\
\text { mont } \\
\text { hs } \\
(95 \% \\
\text { CI) }\end{array}$ & $\begin{array}{c}\text { Not } \\
\text { estima } \\
\text { ble }\end{array}$ & $\begin{array}{l}8.8 \\
\\
(7.9 \\
\text { to not } \\
\text { estim } \\
\text { able) }\end{array}$ & $\begin{array}{c}20.1 \\
(16.7 \\
\text { to } \\
23.4)\end{array}$ & $\begin{array}{c}19.2 \\
(17.5 \\
\text { to } \\
22.3)\end{array}$ & $\begin{array}{l}25.0 \\
(21.8 \\
\text { to not } \\
\text { estim } \\
\text { able })\end{array}$ & $\begin{array}{c}19.6 \\
(17.6 \\
\text { to } \\
23.1)\end{array}$ & $\begin{array}{c}21.4 \\
\text { (18.7 to } \\
\text { not } \\
\text { estimab } \\
\text { le) }\end{array}$ & $\begin{array}{c}16.5 \\
(14.7 \\
\text { to } \\
18.8)\end{array}$ & $\begin{array}{c}25.5 \\
(16.4 \\
\text { to } \\
32.1)\end{array}$ & $\begin{array}{c}19.1 \\
(13.6 \\
\text { to } \\
26.2)\end{array}$ & $\begin{array}{c}15.4 \\
(11.8 \\
\text { to } \\
20.6)\end{array}$ & $\begin{array}{l}17.8 \\
\text { (not } \\
\text { repor } \\
\text { ted) }\end{array}$ & $\begin{array}{l}15.2 \\
\text { (not } \\
\text { repo } \\
\text { rted) }\end{array}$ \\
\hline $\begin{array}{l}\text { OS } \\
\text { Hazar } \\
\text { d } \\
\text { Ratio } \\
(95 \% \\
\text { CI) }\end{array}$ & \multicolumn{2}{|c|}{$\begin{array}{c}0.83(0.50- \\
1.37)\end{array}$} & \multicolumn{2}{|c|}{$\begin{array}{c}0.969 \\
(0.800 \text { to } \\
1.174 ; \mathrm{p}= \\
0.3744)\end{array}$} & \multicolumn{2}{|c|}{$\begin{array}{c}0.73 \\
\text { (95.5\% CI } 0.57 \\
\text { to } 0.93 ; \mathrm{p}= \\
0.002)\end{array}$} & \multicolumn{2}{|c|}{$\begin{array}{c}0.66 \\
(0.53-0.83 ; p= \\
0.00026)\end{array}$} & \multicolumn{3}{|c|}{$\begin{array}{c}0.59 \\
(0.36 \text { to } 0.96 ; p=0.065)\end{array}$} & \multicolumn{2}{|c|}{$\begin{array}{c}0.88 \\
(0.74 \text { to } 1.04 ; \\
p=0.146^{*} \\
\mathrm{~N} / \mathrm{S})\end{array}$} \\
\hline $\begin{array}{l}\text { ORR } \\
(95 \% \\
\text { CI) }\end{array}$ & $\begin{array}{l}1 \% \\
\text { (not } \\
\text { report } \\
\text { ed) }\end{array}$ & $\begin{array}{l}0 \% \\
\text { (not } \\
\text { repor } \\
\text { ted) }\end{array}$ & $\begin{array}{l}19 \% \\
\text { (not } \\
\text { repo } \\
\text { rted) }\end{array}$ & $\begin{array}{l}9 \% \\
\text { (not } \\
\text { repor } \\
\text { ted) }\end{array}$ & $\begin{array}{l}25 \% \\
\text { (not } \\
\text { report } \\
\text { ed) }\end{array}$ & $\begin{array}{c}5 \% \\
\text { (not } \\
\text { report } \\
\text { ed) }\end{array}$ & $\begin{array}{c}17 \% \\
(13 \% \\
\text { to } \\
22 \%)\end{array}$ & $\begin{array}{c}3 \% \\
(2 \% \text { to } \\
6 \% ; \\
\mathrm{p}<0.0 \\
001)\end{array}$ & $\begin{array}{c}35 \% \\
(22 \% \\
\text { to } \\
50 \%)\end{array}$ & $\begin{array}{c}39 \% \\
(25 \% \\
\text { to } \\
53 \%)\end{array}$ & $\begin{array}{c}0 \% \\
(0 \% \text { to } \\
7 \%)\end{array}$ & $\begin{array}{c}10 \% \\
(7 \% \\
\text { to } \\
13 \%)\end{array}$ & $\begin{array}{c}2 \% \\
1 \% \\
\text { to } \\
4 \%)\end{array}$ \\
\hline
\end{tabular}

${ }^{*} \mathrm{~N} / \mathrm{S}$; did not meet the prespecified boundary for significance. ORR = objective response rate; OS = overall survival; PFS = progression free survival

\section{Impact of first line treatment on choice of subsequent lines of therapy}

The second line treatment of mRCC is evolving as the composition of first line treatment changes. Treatment sequencing depends on exposure to first line treatment, prior toxicity, patient and disease factors, and regional funding and regulatory issues.

\section{Following First Line TKI (Sunitinib or Pazopanib)}

For the foreseeable future favorable risk patients in Australia will continue to receive first line sunitinib or pazopanib. In Australia, established treatments that have demonstrated an OS advantage after progression on a VEGF TKI include nivolumab and cabozantinib, both of which

This article is protected by copyright. All rights reserved. 
are PBS listed and have improved outcomes compared with everolimus. Based on a smaller trial improving PFS, lenvatinib plus everolimus remains a viable alternative, but is not PBS listed and the combination is associated with a high rate of treatment-limiting toxicity.

\section{Following First Line Ipilimumab with Nivolumab}

A majority of Australian patients with intermediate or unfavorable risk disease are likely to receive first line ipilimumab plus nivolumab. Following first line treatment with ipilimumab plus nivolumab a VEGF TKI is recommended, supported by an evolving evidence base.

Data for specific TKI treatment following PD-L1 / PD-1 based regimens is available for axitinib from a phase 2 study demonstrating an ORR of 39\%.50 Of the patients treated in the study, 17\% had previously received ipilimumab plus nivolumab and 74\% prior single agent PD-L1 / PD-1. A majority of these patients has also received a prior TKI (sunitinib or pazopanib) during earlier lines of treatment. Cabozantinib use is supported by data from nivolumab pre-treated patients $(\mathrm{n}=18)$ in the METEOR study demonstrating an ORR of $22 \%$, most patients had also received prior TKI treatment. ${ }^{51}$ Pooled data analysis for TKI therapy in patients progressing on ipilimumab plus nivolumab (from CHECKMATE-214) have shown ORR of between $36 \%$ and $45 \%$ with most patients receiving prior sunitinib or pazopanib. 52

In Australia, due to PBS restrictions, pazopanib and sunitinib are the only reimbursed options following first line ipilimumab plus nivolumab for intermediate risk patients, with no subsidized treatment for unfavorable risk patients. The potential for residual effects of IO and overlapping toxicity needs to be considered when selecting second line therapy, such as the potential for hepatitis using pazopanib if immune-mediated hepatitis has been a first line toxicity.

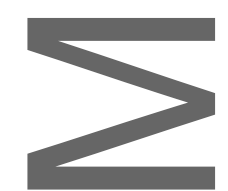

Figure 1 Recommendations for first and second line PBS reimbursed treatment of clear cell metastatic renal cell carcinoma in Australia
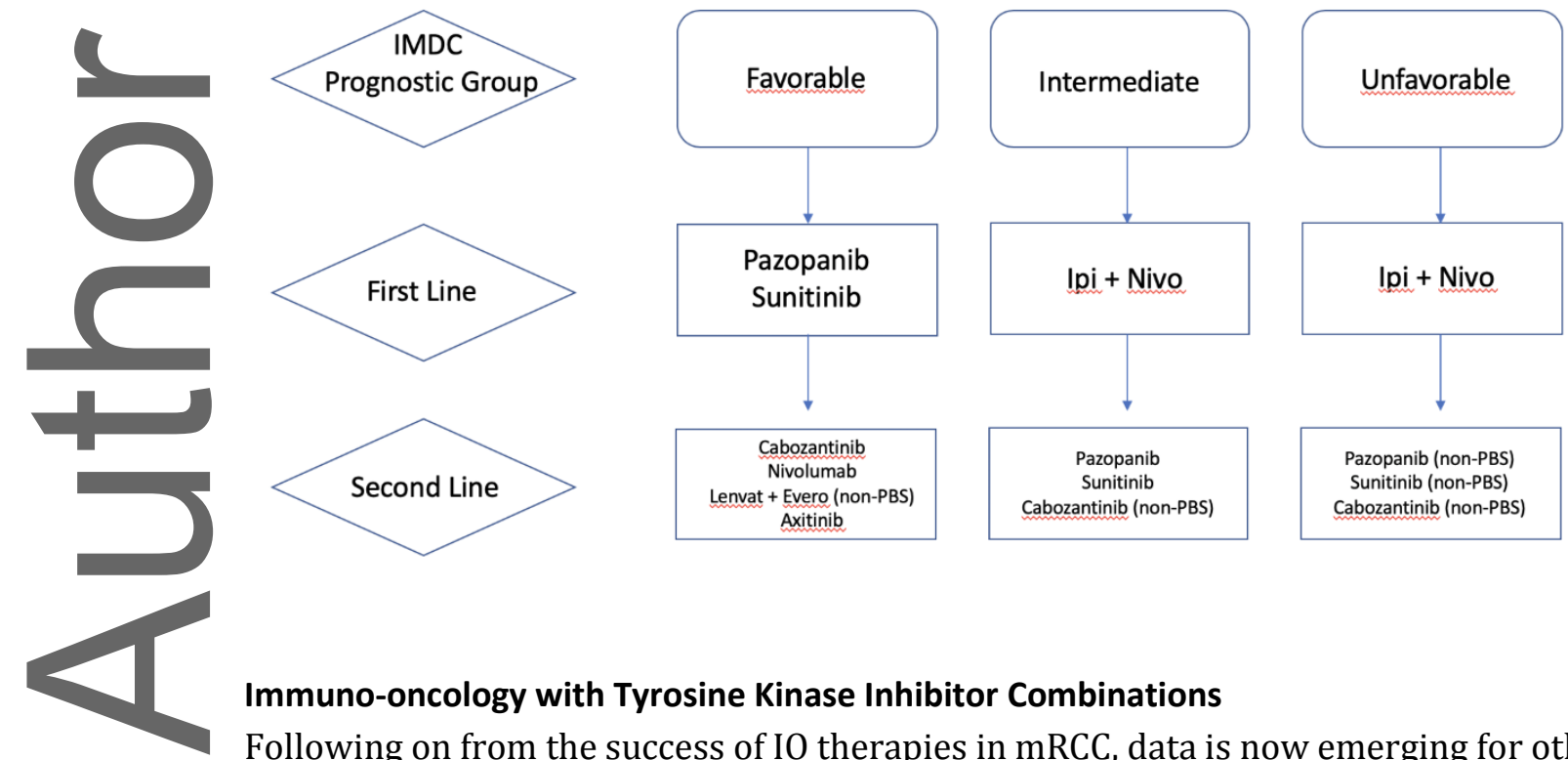

\section{Immuno-oncology with Tyrosine Kinase Inhibitor Combinations}

Following on from the success of IO therapies in mRCC, data is now emerging for other additional IO combination therapies, looking at both IO-TKI combinations and IO-IO combinations utilizing a PD-1 or PD-L1 backbone. Although not yet registered as combination treatment or reimbursed in Australia, the most promising has been axitinib in combination with pembrolizumab which if registered would represent a new standard of care for patients with

This article is protected by copyright. All rights reserved. 
favorable risk disease who are suitable for IO therapy, and an additional option for patients with intermediate or unfavorable risk disease (HR for death, $0.53 ; 95 \% \mathrm{CI}, 0.38$ to $0.74 ; \mathrm{P}<0.0001$ ). ${ }^{6}$

\section{Summary}

Key considerations for patient selection and first line treatment decisions involve careful assessment of prognostic risk criteria, patient preference, reimbursement options as well as the rapidly evolving evidence base for treatment selection. Early studies of VEGF TKIs showed improvements in PFS over established treatments, however, with the new era of combination IO therapies, OS has increased significantly.

Baseline prognostic factors have historically informed prognosis and now help guide treatment selection for patients. This is important to recognize as current treatment options are based on the IMDC prognostic group, calculated based on baseline clinical and laboratory parameters.

Favorable risk patients should receive treatment with VEGF TKI, but intermediate and unfavorable risk disease should be treated with combination ipilimumab and nivolumab, which has demonstrated an OS advantage. Some patients are not suitable for first line immunotherapy based treatment, including those with an organ transplant or concurrent flare of auto-immune disease and a VEGF TKI may be more appropriate.

Future research on other combination options and research on drug sequencing in subsequent lines will become an important research focus in the future.

\section{Disclosures}

Andrew Schmidt has no disclosures. Arun Azad has provided consultation services to Astellas, Janssen and Novartis; has attended speakers bureaus for Astellas, Janssen, Novartis and Amgen; has received honoraria from Astellas, Janssen, Novartis, Tolmar, Amgen, Pfizer, and Telix; has participated in scientific advisory board meetings for Astellas, Novartis, Sanofi, AstraZeneca, Tolmar, Pfizer and Telix; and has received research funding from Astellas and Merck. Jeffrey Goh has provided consultation services and participated in scientific advisory board meetings for Bristol-Myers Squibb, AstraZeneca, Merck Sharp \& Dohme and Janssen; and has attended speakers bureaus for Novartis, Ipsen, AstraZeneca, Merck Sharp \& Dohme and Janssen. Carole Harris has no disclosures. Anthony Joshua has no disclosures. Andrew Weickhardt has received honoraria from Bristol-Myers Squibb and Merck; has received funding for travel from Astellas; has participated in scientific advisory board meetings for Merck, Ipsen, Pfizer and Bristol-Myers Squibb; and has received research funding from Bristol-Myers Squibb. Laurence Krieger has provided consultation services to Astellas, Janssen, Novartis, Ipsen, Pfizer, Bristol-Myers Squibb and AstraZeneca; has attended speakers bureaus for Astellas, Bristol-Myers Squibb, Amgen, Novartis, Ipsen, Pfizer and AstraZeneca; and has participated in scientific advisory board meetings for Astellas, Novartis, Sanofi, AstraZeneca, Pfizer, Janssen and Bristol-Myers Squibb. 


\section{References}

1. Australian Institute of Health and Welfare. Cancer in Australia. In:2017.

2. Drug utilisation sub-committee (DUSC). Pazopanib and sunitinib for renal cell carcinoma: analysis of predicted versus actual utilisation. 2014; http://www.pbs.gov.au/industry/listing/participants/public-release-docs/pazopanibsunitinib/pazopanib-sunitinib.pdf.

3. Hsieh JJ, Purdue MP, Signoretti S, et al. Renal cell carcinoma. Nat Rev Dis Primers. 2017;3:17009.

4. Motzer RJ, Hutson TE, Tomczak P, et al. Sunitinib versus interferon alfa in metastatic renal-cell carcinoma. $N$ Engl J Med. 2007;356(2):115-124.

5. Motzer RJ, Tannir NM, McDermott DF, et al. Nivolumab plus Ipilimumab versus Sunitinib in Advanced Renal-Cell Carcinoma. 2018;378(14):1277-1290.

6. Rini BI, Plimack ER, Stus V, et al. Pembrolizumab plus Axitinib versus Sunitinib for Advanced Renal-Cell Carcinoma. New Engl J Med. 2019;380:1116-1127.

7. Heng DY, Xie W, Regan MM, et al. Prognostic factors for overall survival in patients with metastatic renal cell carcinoma treated with vascular endothelial growth factor-targeted agents: results from a large, multicenter study. J Clin Oncol. 2009;27(34):5794-5799.

8. Motzer RJ, Mazumdar M, Bacik J, Berg W, Amsterdam A, Ferrara J. Survival and prognostic stratification of 670 patients with advanced renal cell carcinoma. J Clin Oncol. 1999;17(8):2530-2540.

9. Heng DYC, Xie W, Regan MM, et al. External validation and comparison with other models of the International Metastatic Renal-Cell Carcinoma Database Consortium prognostic model: a population-based study. The Lancet Oncology. 2013;14(2):141-148.

10. Escudier B, Porta C, Schmidinger M, et al. Renal cell carcinoma: ESMO Clinical Practice Guidelines for diagnosis, treatment and follow-updagger. Ann Oncol. 2019;30(5):706720.

11. National Comprehensive Cancer Network. NCCN Clinical Practice Guidelines in Oncology: Kidney Cancer; Version 1.2020. In:2019.

12. Kushnir I, Basappa NS, Ghosh S, et al. Active surveillance in metastatic renal cell carcinoma (mRCC): Results from the Canadian Kidney Cancer information system (CKCis). J Clin Oncol. 2019;37(15_suppl):4516-4516.

13. Rini BI, Dorff TB, Elson P, et al. Active surveillance in metastatic renal-cell carcinoma: a prospective, phase 2 trial. Lancet Oncol. 2016;17(9):1317-1324.

14. Ouzaid I, Capitanio U, Staehler M, et al. Surgical Metastasectomy in Renal Cell Carcinoma: A Systematic Review. Eur Urol Oncol. 2019;2(2):141-149.

15. Mejean A, Thezenas S, Chevreau C, et al. Cytoreductive nephrectomy (CN) in metastatic renal cancer (mRCC): Update on Carmena trial with focus on intermediate IMDC-risk population. J Clin Oncol. 2019;37(15 suppl; abstr 4508).

This article is protected by copyright. All rights reserved. 
16. Flanigan RC, Mickisch G, Sylvester R, Tangen C, Van Poppel H, Crawford ED. Cytoreductive nephrectomy in patients with metastatic renal cancer: a combined analysis. J Urol. 2004;171(3):1071-1076.

17. Flanigan RC, Salmon SE, Blumenstein BA, et al. Nephrectomy followed by interferon alfa$2 \mathrm{~b}$ compared with interferon alfa-2b alone for metastatic renal-cell cancer. $N$ Engl J Med. 2001;345(23):1655-1659.

18. Mickisch GH, Garin A, van Poppel H, de Prijck L, Sylvester R. Radical nephrectomy plus interferon-alfa-based immunotherapy compared with interferon alfa alone in metastatic renal-cell carcinoma: a randomised trial. Lancet. 2001;358(9286):966-970.

19. Bex A, Mulders P, Jewett M, et al. Comparison of Immediate vs Deferred Cytoreductive Nephrectomy in Patients with Synchronous Metastatic Renal Cell Carcinoma Receiving Sunitinib: The SURTIME Randomized Clinical Trial. JAMA Oncol. 2018;1(5 (2)):164-170.

20. Mejean A, Ravaud A, Thezenas S, et al. Sunitinib Alone or after Nephrectomy in Metastatic Renal-Cell Carcinoma. 2018;379(5):417-427.

21. ClinicalTrials.gov. Deferred Cytoreductive Nephrectomy in Synchronous Metastatic Renal Cell Carcinoma: The NORDIC-SUN-Trial (NORDIC-SUN). 2019; https://clinicaltrials.gov/ct2/show/NCT03977571. Accessed July 2019.

22. Meyer E, Pasquier D, Bernadou G, et al. Stereotactic radiation therapy in the strategy of treatment of metastatic renal cell carcinoma: A study of the Getug group. Eur J Cancer. 2018;98:38-47.

23. Pharmaceutical Benefits Scheme. 2019; http://www.pbs.gov.au/browse/streamlinedauthority.

24. Motzer RJ, Hutson TE, Tomczak P, et al. Overall survival and updated results for sunitinib compared with interferon alfa in patients with metastatic renal cell carcinoma. J Clin Oncol. 2009;27(22):3584-3590.

25. Rini BI, Hutson TE, Figlin RA, et al. Sunitinib in Patients With Metastatic Renal Cell Carcinoma: Clinical Outcome According to International Metastatic Renal Cell Carcinoma Database Consortium Risk Group. Clin Genitourin Cancer. 2018;16(4):298-304.

26. Motzer RJ, Hutson TE, Cella D, et al. Pazopanib versus sunitinib in metastatic renal-cell carcinoma. N Engl J Med. 2013;369(8):722-731.

27. Ruiz-Morales JM, Swierkowski M, Wells JC, et al. First-line sunitinib versus pazopanib in metastatic renal cell carcinoma: Results from the International Metastatic Renal Cell Carcinoma Database Consortium. Eur J Cancer. 2016;65:102-108.

28. Jonasch E, Slack RS, Geynisman DM, et al. Phase II study of two weeks on, one week off sunitinib scheduling in patients with metastatic renal cell carcinoma. J Clin Oncol. 2018;36(16):1588-1593.

29. Bjarnason GA, Knox JJ, Kollmannsberger CK, et al. The efficacy and safety of sunitinib given on an individualised schedule as first-line therapy for metastatic renal cell carcinoma: A phase 2 clinical trial. Eur J Cancer. 2019;108:69-77.

30. Escudier B, Motzer RJ, Tannir NM, et al. Consistent efficacy of nivolumab plus ipilimumab across number of International Metastatic Database Consortium (IMDC) risk factors in CheckMate 214. J Clin Oncol. 2019;37.

This article is protected by copyright. All rights reserved. 
31. Danlos FX, Voisin AL, Dyevre V, et al. Safety and efficacy of anti-programmed death 1 antibodies in patients with cancer and pre-existing autoimmune or inflammatory disease. Eur J Cancer. 2018;91:21-29.

32. Menzies AM, Johnson DB, Ramanujam S, et al. Anti-PD-1 therapy in patients with advanced melanoma and preexisting autoimmune disorders or major toxicity with ipilimumab. Ann Oncol. 2017;28(2):368-376.

33. Cook MR, Kim C. Safety and Efficacy of Immune Checkpoint Inhibitor Therapy in Patients With HIV Infection and Advanced-Stage Cancer: A Systematic ReviewImmune Checkpoint Inhibitor Therapy in Patients With HIV Infection and Advanced-Stage CancerImmune Checkpoint Inhibitor Therapy in Patients With HIV Infection and Advanced-Stage Cancer. JAMA Oncology. 2019;5(7):1049-1054.

34. Shah NJ. Real-world outcomes of underrepresented patient populations treated with immune checkpoint inhibitors (ICIs): African American descent, poor ECOG performance status, and chronic viral infections. Paper presented at: ASCO 2019.

35. Tio M, Rai R, Ezeoke OM, et al. Anti-PD-1/PD-L1 immunotherapy in patients with solid organ transplant, HIV or hepatitis B/C infection. Eur J Cancer. 2018;104:137-144.

36. Abdel-Wahab N, Safa H, Abudayyeh A, et al. Checkpoint inhibitor therapy for cancer in solid organ transplantation recipients: an institutional experience and a systematic review of the literature. J Immunother Cancer. 2019;7(1):106.

37. De Bruyn P, Van Gestel D, Ost P, et al. Immune checkpoint blockade for organ transplant patients with advanced cancer: how far can we go? Curr Opin Oncol. 2019;31(2):54-64.

38. Ipsen Pty Ltd. Cabozantinib Product Information. In:2019.

39. Motzer RJ, Escudier B, McDermott DF, et al. Nivolumab versus Everolimus in Advanced Renal-Cell Carcinoma. N Engl J Med. 2015;373(19):1803-1813.

40. Choueiri TK, Escudier B, Powles T, et al. Cabozantinib versus Everolimus in Advanced Renal-Cell Carcinoma. N Engl J Med. 2015;373(19):1814-1823.

41. Choueiri TK, Escudier B, Powles T, et al. Cabozantinib versus everolimus in advanced renal cell carcinoma (METEOR): final results from a randomised, open-label, phase 3 trial. Lancet Oncol. 2016;17(7):917-927.

42. Motzer RJ, Hutson TE, Glen H, et al. Lenvatinib, everolimus, and the combination in patients with metastatic renal cell carcinoma: a randomised, phase 2, open-label, multicentre trial. Lancet Oncol. 2015;16(15):1473-1482.

43. Hutson TE, Dutcus CE, Ren M, Baig MA, Fishman MN. Subgroup analyses and updated overall survival from the phase II trial of lenvatinib (LEN), everolimus (EVE), and LEN+EVE in metastatic renal cell carcinoma (mRCC). J Clin Oncol. 2016;34.

44. Motzer RJ, Hutson TE, Ren M, Dutcus C, Larkin J. Independent assessment of lenvatinib plus everolimus in patients with metastatic renal cell carcinoma. Lancet Oncol. 2016;17(1):e4-5.

45. Rini BI, Escudier B, Tomczak P, et al. Comparative effectiveness of axitinib versus sorafenib in advanced renal cell carcinoma (AXIS): a randomised phase 3 trial. Lancet. 2011;378(9807):1931-1939.

This article is protected by copyright. All rights reserved. 
46. Motzer RJ, Escudier B, Oudard S, et al. Efficacy of everolimus in advanced renal cell carcinoma: a double-blind, randomised, placebo-controlled phase III trial. Lancet. 2008;372(9637):449-456.

47. Escudier B, Eisen T, Stadler WM, et al. Sorafenib in advanced clear-cell renal-cell carcinoma. $N$ Engl J Med. 2007;356(2):125-134.

48. Motzer RJ, Escudier B, Tomczak P, et al. Axitinib versus sorafenib as second-line treatment for advanced renal cell carcinoma: overall survival analysis and updated results from a randomised phase 3 trial. Lancet Oncol. 2013;14(6):552-562.

49. Escudier B, Eisen T, Stadler WM, et al. Sorafenib for treatment of renal cell carcinoma: Final efficacy and safety results of the phase III treatment approaches in renal cancer global evaluation trial. J Clin Oncol. 2009;27(20):3312-3318.

50. Ornstein MC, Pal SK, Wood LS, et al. Prospective phase II multi-center study of individualized axitinib (Axi) titration for metastatic renal cell carcinoma (mRCC) after treatment with PD-1 / PD-L1 inhibitors. J Clin Oncol. 2018;36:4517.

51. Powles T, Motzer RJ, Escudier B, et al. Outcomes based on prior therapy in the phase 3 METEOR trial of cabozantinib versus everolimus in advanced renal cell carcinoma. $\mathrm{Br} \mathrm{J}$ Cancer. 2018;119(6):663-669.

52. Auvray M, Auclin E, Barthelemy P, et al. Second-line targeted therapies after nivolumabipilimumab failure in metastatic renal cell carcinoma. Eur J Cancer. 2019;108:33-40.

This article is protected by copyright. All rights reserved. 


\section{University Library}

\section{- M M N E R VA A gateway to Melbourne's research publications}

Minerva Access is the Institutional Repository of The University of Melbourne

Author/s:

Schmidt, A;Azad, A;Goh, J;Harris, C;Joshua, AM;Weickhardt, A;Krieger, L

Title:

Treatment selection for first-line metastatic renal cell carcinoma in Australia: Impact of new therapy options

Date:

2019-11-01

\section{Citation:}

Schmidt, A., Azad, A., Goh, J., Harris, C., Joshua, A. M., Weickhardt, A. \& Krieger, L. (2019). Treatment selection for first-line metastatic renal cell carcinoma in Australia: Impact of new therapy options. ASIA-PACIFIC JOURNAL OF CLINICAL ONCOLOGY, 15 (S10), pp.3-10. https://doi.org/10.1111/ajco.13289.

Persistent Link:

http://hdl.handle.net/11343/286573 